\title{
Exploring the trends of educational virtual reality games: a systematic review of empirical studies
}

Solomon Sunday Oyelere ${ }^{1 *}$ (D) Nacir Bouali ${ }^{1,2}$, Rogers Kaliisa ${ }^{3}$, George Obaido $^{4}$, Abdullahi Abubakar Yunusa $^{5}$ and Ebunayo R. Jimoh ${ }^{6}$

* Correspondence: solomon. oyelere@uef.fi

${ }^{1}$ University of Eastern Finland, School of Computing, Joensuu, Finland

Full list of author information is available at the end of the article

\begin{abstract}
Virtual Reality (VR) and educational games are emerging technologies mediating a rapid transformation in the educational world. However, few studies have systematically analyzed Educational Virtual Reality Games (EVRGs) and how they have been applied in educational settings. This study reviewed 31 articles published in high impact journals and educational conference proceedings to unravel the technological, pedagogical, and gaming characteristics of contemporary EVRGs. The results show the predominance of Oculus Rift headsets and HTC Vive as the main technology used in EVRGs. Moreover, the analysis revealed that the pedagogical application of the majority of EVRGs was developed for all levels of education (e.g. tertiary, K-12, lifelong learning), with the specific target audience of each game based on the desired learning outcome. Furthermore, the application of EVRGs has primarily focused on out of class use, with healthcare education topics dominating the topics taught using EVRGs. Based on our findings, we highlight some key implications and suggestions to advance the field of EVRGs.
\end{abstract}

Keywords: Educational games, Virtual reality, Educational virtual reality games, Systematic review

\section{Introduction}

This study explores the advances of educational virtual reality games (EVRGs) and expounds its important developmental features such as technology, pedagogy and gaming. The rapid development in Information and Communication Technology (ICT) has revolutionized the computing industry and propelled a paradigm shift in the pedagogy of teaching and learning (Kaliisa, Edward, \& Julia, 2019; Oyelere, Suhonen, Wajiga, \& Sutinen, 2018). Contemporary computer hardware and software have improved significantly in size, speed, and precision, and a key to the creation of immersive technological applications (Bekele, Pierdicca, Frontoni, Malinverni, \& Gain, 2018; Voinea, Girbacia, Postelnicu, \& Marto, 2018). Virtual reality (VR) is a technology that has recently gained prominence as one of the core features of modern 'high-tech' with wideranging applications, including education (Virvou \& Katsionis, 2008), gaming (Zyda,

(c) The Author(s). 2020 Open Access This article is licensed under a Creative Commons Attribution 4.0 International License, which permits use, sharing, adaptation, distribution and reproduction in any medium or format, as long as you give appropriate credit to the original author(s) and the source, provide a link to the Creative Commons licence, and indicate if changes were made. The images or other third party material in this article are included in the article's Creative Commons licence, unless indicated otherwise in a credit line to the material. If material is not included in the article's Creative Commons licence and your intended use is not permitted by statutory regulation or exceeds the permitted use, you will need to obtain permission directly from the copyright holder. To view a copy of this licence, visit http://creativecommons.org/licenses/by/4.0/. 
2005), entertainment (Liu, Cheok, Mei-Ling, \& Theng, 2007), military (Lele, 2013), skills training (Aggarwal, Black, Hance, Darzi, \& Cheshire, 2006), tourism (Tussyadiah, Wang, Jung, \& Dieck, 2018), as well as physical exercise (Finkelstein et al., 2011). VR is computer-simulated, which gives users the illusion of being physically present in the world and uses not only sight but also sound and touch to fully engage a user in the virtual world (Mandal, 2013).

In this paper, we refer to VR as the experience in which a user is fully immersed into either a virtual environment using head-mounted displays (headsets) or projectionbased displays. A user through the utilization of an avatar (Carvalheiro, Nóbrega, da Silva, \& Rodrigues, 2016) can as a result, navigate this world. This functionality differs from 3D environments visualized using headsets, but the user is only able to experience the virtual world from a fixed perspective and an onscreen visualizable threedimensional (3D) environment. In this research, educational games are defined as the games designed, implemented, and evaluated with the purpose of teaching, or aiding in the instruction of a subject, or aiding in the learning of a specific skill within a formal or an informal setting (Oyelere, Suhonen, \& Laine, 2017; Pavlidis \& Markantonatou, 2018). We define Educational Virtual Reality Games (EVRGs) as educational games that exploit the 3D stereoscopic display, using a wearable headset or a Cave Automatic Virtual Environment (CAVE) system to teach or aid in the instruction of a specific topic. With such a definition non-immersive educational VR games, wherein the user navigates a virtual world using an avatar controlled by a mouse and a keyboard and/or a joystick, have been excluded.

VR technology has become increasingly a popular teaching and learning support tool across different disciplines. It provides an opportunity for students and teachers to experience, as well as interact, with real-time learning phenomena, something that would have been almost impossible in the physical world (Shin, 2017; Vesisenaho et al., 2019). VR allows for the use of multiple senses (e.g., touch, sense of heat, smell), which are used simultaneously during the learning process. In this regard, this could improve the activeness and mental alertness of both the students and teachers. This claim is supported by Lee and Wong (2014) who concluded that there is a significant interaction effect between the learning mode and the spatial ability of the students. Furthermore, other studies have established the pedagogical benefits of VR, such as the ability to support students with diverse learning styles in gaining cognitive achievement (Lee, Wong, \& Fung, 2010), improving spatial thinking (Cohen \& Hegarty, 2014), learning objectoriented programming concepts (Bouali, Nygren, Oyelere, Suhonen, \& Cavalli-Sforza, 2019), and in facilitating collaboration (Greenwald et al., 2017).

The goal of this study was to systematically review the trends of EVRGs from the perspective of their technological, pedagogical, and gaming characteristics. The study draws on research conducted by Laine (2018), by focusing on studies that describe the design, implementation, and evaluation of EVRGs. Since Laine's (2018) study focuses strictly on mobile Augmented Reality Games (ARs), our work provides a slightly different and more comprehensive perspective by focusing on EVRGs. A review of previous studies of EVRGs would make it possible to understand in which direction the field is heading and how future EVRGs should be designed to best fit the needs of both the teacher and students to improve educational outcomes. We argue that a review of EVRGs is needed (i) to understand and conceptualize the existing body of EVRGs; (ii) 
to provide evidence about the technologies that support the implementation of EVRGs across a wide range of settings and techniques used; (iii) to explore the teaching and learning attributes of VR games and how different pedagogical characteristics such as context, topics taught, and types of learners have changed over the years. We further aim (iv) to develop a set of pointers to researchers and practitioners (e.g. teachers) interested in conducting and applying VR games in research and pedagogical practice; and (v) to understand the characteristics of contemporary games to supporting educational developments. To achieve these goals, we, therefore, seek to answer the research question: What are the technological, pedagogical, and gaming characteristics of contemporary educational VR games?

The rest of the paper is organized as follows: presentation of related work, the methodology, and conclusion with several remarks that reinforce the critical points regarding the use of educational VR games.

\section{Related work}

\section{Relationship between VR and education}

The educational process requires the learner to grasp and comprehend abstract concepts and appreciate scenarios, as well as to understand situations which are far removed from the confines of the classroom. Duffy and Jonassen (1992) argue that the teaching of abstract phenomena, analogy and lived experiences are used to describe and ease through abstract concepts from commonly observable reality. However, over the last decade, the application of emerging technologies in education have revolutionized the pedagogical or teaching processes in the classroom, to explain better and to provide comprehension of abstract concepts.

VR is an emerging technology that has gained traction in education. Educationists have discovered that VR allows the user to interact with a computer-generated 3D model or virtual environment (Christou, 2010) which fosters the understanding of the imaginary world on a realistic scale. This makes it a useful tool for teaching and learning by transforming the way educational content is delivered (Hentsch, 2018). A study by Lee and Wong (2008), described VR as a technology that aids student learning through the visualization of information and engagement, which affords a learner with the opportunity to experience subject matter or concepts that are not easily discernible.

VR does not only relate positively to education but aligns with the constructivism school of thought, which stipulates that humans construct knowledge by learning from experience. The constructivist theory advocates that learning through interaction with sensory data allows knowledge construction from experience for which VR is suited. Christou (2010), chronicled broad application areas of VR in educational contexts used in the enhancement of core curricula in schools and colleges, application of VR in museums, edutainment, demonstrations, simulation, and training.

\section{Comparison of VR and 3D games in education}

In the past few decades, game-based learning has been an integral part of the educational process (Boboc, Orzan, Stoica, \& Niculescu-Ciocan, 2018; Hwang, Wu, Chen, \& Tu, 2016; Xenos, Maratou, Ntokas, Mettouris, \& Papadopoulos, 2017). EVRGs are designed to assist users to grasp the concepts of a specific subject, to expand their 
knowledge, and to facilitate participation. A typical example of educational virtual reality game is GridlockED, which was developed by Tsoy et al. (2019) as a collaborative learning game, targeted for medical trainees, to acquire the skills on how to treat and triage a patient. Modern educational games are played using high-end video technology such as stereoscopic 3D, or through a Head-Mounted VR environment (Snowdon \& Oikonomou, 2018). These technologies use a spatial depth on the screen and offer rich learning experiences for the user.

A study by Sampaio, Ferreira, Rosário, and Martins (2010) described 3D technology as that which creates spatial depth with 3D pop-up visualizations so that objects contained in the game may appear closer to the player with the use of dedicated 3Dcapable glasses. In comparison to the 3D technology, Triberti, Villani, and Riva (2016) described VR as a computer-simulated reality that uses a 3D environment whereby the player interacts with using a specialized head-mounted display (e.g. Oculus Rift, Samsung Gear VR, Google Cardboard etc.) that shows visual effects to the eyes. Unlike 3D, where the user is a just a viewer, VR allows for the user to become part of a story, offering an untethered immersive experience (Bradshaw, 2016). Therefore, a video game in VR is more realistic than one played in a 3D condition. Hence, VR technology could be applied to complement 3D modelling, ensuring better communication both in an educational or vocational training (Bradshaw, 2016). A comparative study by Roettl and Terlutter (2018) on 237 players showed that the participation and cognitive load was much higher in players using VR than just 3D. Recently, researchers have critically debated on the effects of 3D and VR technologies on issues such as adverse effects like social isolation (Nicas, 2018), discomfort, eye fatigue, and headache when using these technologies for an extended period (Bradshaw, 2016; Roettl \& Terlutter, 2018; Sharkawi, Ujang, \& Abdul-Rahman, 2008).

\section{Related EVRGs reviews}

Since this article focuses on exploring current EVRGs, we consider it vital to summarize in a tabular form the existing efforts in this direction. Table 1 presents the previous attempts to review works in EVRGs.

As can be observed from the existing studies reviewing EVRGs (Table 1), the field of VR games has garnered interest amongst educational technology researchers. This may be partly as a result of an increase in innovation within the field as well as in the

Table 1 Related literature on educational virtual reality games within the systematic review

\begin{tabular}{|c|c|c|c|c|}
\hline Review & $\begin{array}{l}\text { Year of } \\
\text { publication }\end{array}$ & Focus & $\begin{array}{l}\text { Number of } \\
\text { studies }\end{array}$ & $\begin{array}{l}\text { Year range of } \\
\text { reviewed studies }\end{array}$ \\
\hline $\begin{array}{l}\text { Immersive VR serious games for } \\
\text { evacuation training and research: A } \\
\text { systematic literature review }\end{array}$ & 2018 & $\begin{array}{l}\text { VR Serious Games } \\
\text { for Evacuation } \\
\text { Training }\end{array}$ & 15 & $2007-2017$ \\
\hline $\begin{array}{l}\text { A Literature Review on Immersive VR in } \\
\text { Education: State of the Art and } \\
\text { Perspectives }\end{array}$ & 2015 & $\begin{array}{l}\text { Advantages of } \\
\text { using VR in } \\
\text { education }\end{array}$ & 93 & 2013-2014 \\
\hline $\begin{array}{l}\text { Computer Technology for Serious } \\
\text { Games in Education: A Literature } \\
\text { Review }\end{array}$ & 2017 & $\begin{array}{l}\text { Serious Games in } \\
\text { General with a } \\
\text { focus on VR }\end{array}$ & $\begin{array}{l}6 \text { (counting } \\
\text { only VR } \\
\text { serious games) }\end{array}$ & $2006-2016$ \\
\hline Using VR in Education & 2017 & $\begin{array}{l}\text { Reviewed VR } \\
\text { headsets }\end{array}$ & 2 & $2012-2017$ \\
\hline
\end{tabular}


variation in the pedagogical application of VR. However, to the best of our knowledge and evaluation of the existing reviews, no study has attempted to review systematically the trends of EVRGs accounting from the viewpoints of technology, pedagogy, content, knowledge, and games. To bridge this gap, this paper centers in a systematic literature review to examine the current research on EVRGs and to provide important insights beyond the specific research findings within the individual studies.

\section{Methodology}

This study follows the guidelines for conducting a systematic literature review by Kitchenham and Charters (2007) (Fig. 1). The search service of the (blinded for review) library's printed and electronic resources, (blinded for review) was utilized to access databases and extract publications. Google Drive was used for collaboration among the team, and MS Excel spreadsheets were used to manage and organize the information acquired from the search.

\section{Phase 1. Planning the review}

This phase focuses on the initial preparation undertaken to achieve the goal of this literature review.

\section{Phase 1.1 Rationale of the review}

Based on the guidelines by Kitchenham and Charters (2007), we identified previous systematic reviews that addressed either our research questions or similar questions. However, as discussed in the introduction, none of the reviews focused on EVRGs. Thus, we decided to conduct a review on EVRGs with specific attention to attributes such as technology, pedagogy and gaming.

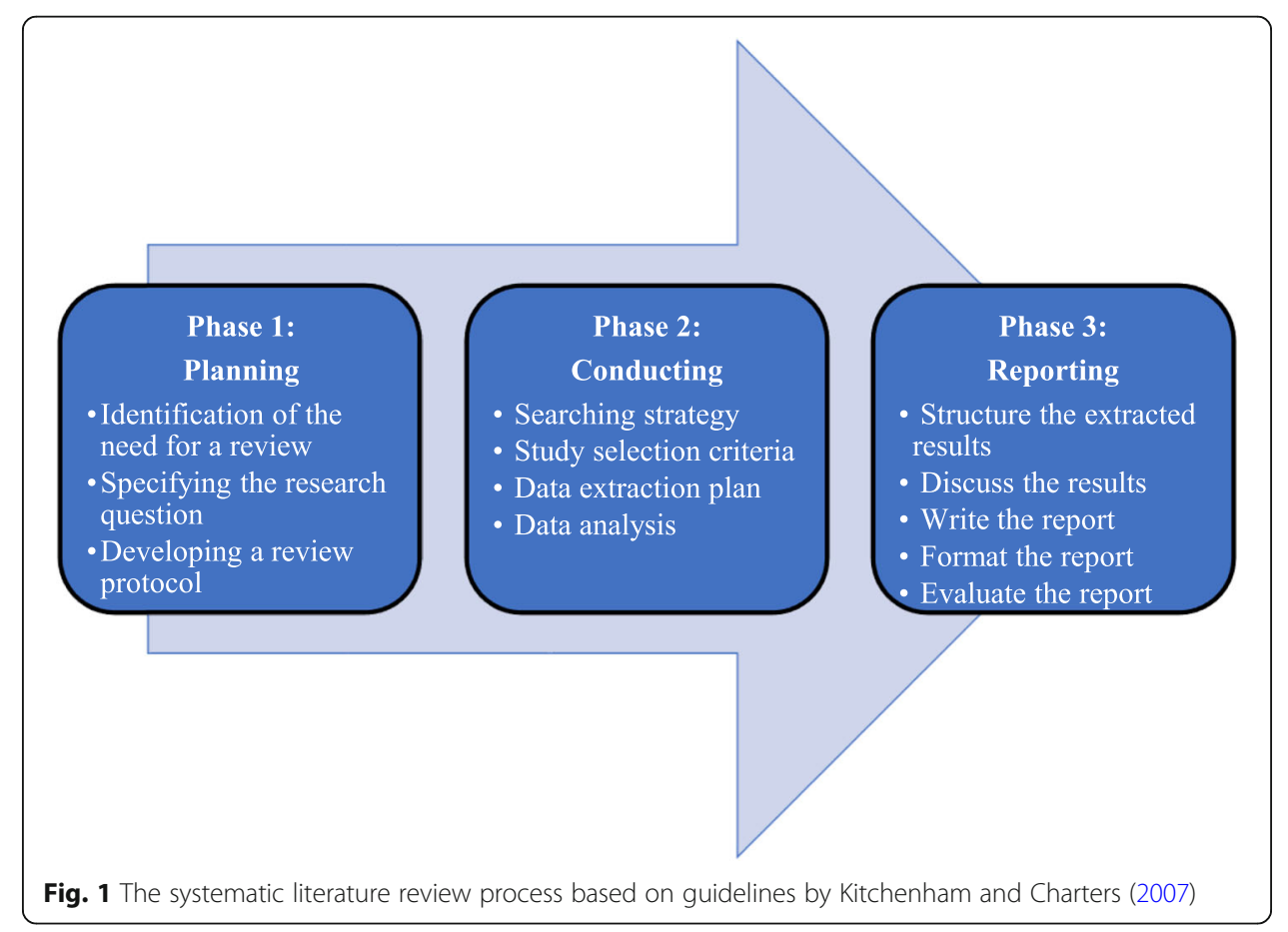


Phase 1.2. Specifying the research question

By drawing on existing accounts about the application of VR games, in the educational sphere, this study set one research question: What are the technological, pedagogical, and gaming characteristics of contemporary educational VR games? To answer this research question, this study analyzed existing research about EVRGs with an emphasis on profiling the games in terms of the country of research, year of production, technological attributes (e.g. platform, types of headsets), pedagogical attributes (e.g., topics, types of learners, educational settings) and the gaming attributes (e.g., player's role, the theme of play, mode, and goal of the game).

\section{Phase 1.3. Developing a review protocol}

According to Kitchenham and Charters (2007), a review protocol provides the basis to carry out the systematic review. Creating a review protocol beforehand helps to reduce the likelihood of research bias, such as potential prejudiced selections of particular studies carried out by the researcher. Formal and informal searches were used to find relevant studies in response to the research question. Table 2 presents the databases and the search strategy of the preliminary searches of existing related studies of EVRGs in education, which set the direction for this study. The databases were selected because they were either specialized in educational technology, educational games or in virtual reality applications, or that have published at least one special issue in educational virtual reality and games for learning. Thereafter, the preliminary review studies presented in Table 1 were used to create the research framework as well as the research question, which yielded a well-organized review protocol.

\section{Phase 2. Conducting the review}

The second phase of the guidelines by Kitchenham and Charters (2007) follows five stages: the search strategy, the study selection criteria, the study quality assessment, the data extraction plan, and the data analysis tool.

\section{Phase 2.1. Search strategy}

The research question of this study guided the formulation and expounding of the search strategy. As a first step, the search keywords were identified as a way of narrowing down and focusing on relevant articles for the topic under study. The search keywords were chosen according to the research theme; research question and the objective of this study (see Table 2 for search strategy and list of databases). Search keywords: The search space was narrowed down using Boolean search phrases and different combinations of the following terms: "virtual reality" AND "education", OR "learning", OR "game", OR "gamification", OR "serious game". While many researchers

Table 2 Search Database

\begin{tabular}{ll}
\hline Database (sources) & Search strategy \\
\hline ACM Digital Library & Title \\
Google Scholar & Alternative search \\
IEEE Xplore & Title \\
ScienceDirect & Alternative search \\
\hline
\end{tabular}


use the term "educational games" to refer to games, the purpose of which is helping a learner acquire a skill, others opt for a more generic term like "serious game". The keyword choice was made in a way to capture any game that is used in an educational context, be it formal or informal, as long as it uses VR technology, with the definition we adopted above. The time frame for publication considered within the systematic review was between 2012 and 2018. Since the field of educational technology and virtual reality games is developing very fast, articles before 2012 have been reviewed in previous studies and are not particularly relevant in this work. The screening was based on titles, abstracts, and full-text skimming and took place from 1 February 2019 to 30 May 2019.

\section{Phase 2.2. Study selection criteria}

Using the keywords and search strings presented in the section "Phase 2.1. Search strategy", several articles were selected based on their relevance to the research question and inclusion criteria. A flow diagram representing the steps of the selection criteria is presented in Fig. 2. The researchers read the title, abstract, keywords and skimmed through the contents of all the papers and selected the articles that appeared to be appropriate based on VR, education, and gamification. Abstracts, posters, books, and articles that did not show an implementation that required a VR headset were excluded. Altogether, we found 162 research papers through the predefined search keywords on the four databases. However, after we applied the inclusion and exclusion criteria (Table 3), only 31 articles made it through the scrutiny (Table 4).

Phase 2.3. Data extraction and analysis

We set up a coding scheme to guide the extraction of relevant data from research articles with relevance to our research question. The coding scheme included the following overarching dimensions: Title/name of the game, description of the game, country of game implementation, player role, theme, mode, gameplay, goal, platform, VR headset, game interaction, focus, learners, educational setting, research, and evaluation methods.

In summary, the methodology section, presented the planning and implementation process of the systematic review and these included; providing the rationale for choosing the framework adopted for the review, specifying the research questions, developing the review protocol, executing the review, identifying the keywords, drafting the study selection criteria as well as data extraction and analysis. Subsequently, the results yielded by these processes are presented in the next section.

\section{Results}

The results are organized in four main categories: A general overview of the EVRGs, technological, pedagogical, and gaming characteristics.

\section{Overview of the VR serious games}

The number of EVRGs publications appearing in each year from 2012 to 2018 is presented in Fig. 3. The bar chart shows a definite increase in the number of research works dedicated to VR educational games. Research shows that there was one study in 2014 and increases to 14 studies in 2018. Table 5 shows that EVRGs have been researched in North and South America, Europe, Asia, and Australia. See Table 5 for full details of serious games. 


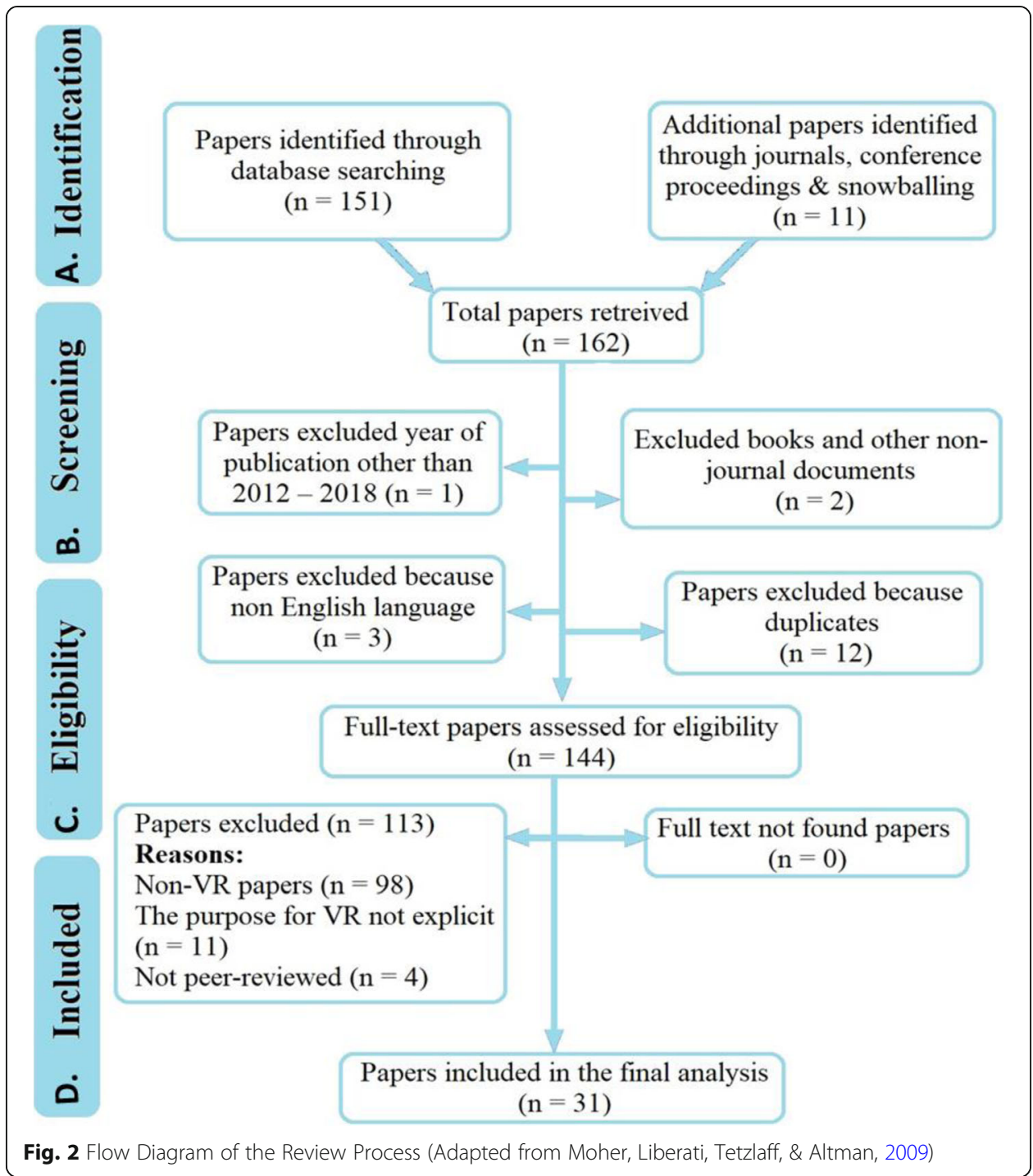

\section{Technological characteristics}

The review looked at the technological characteristics of the selected EVRGs in terms of platform, headset, and interaction components. As shown in Fig. 4, the Oculus Rift seems to dominate the VR headsets used in EVRGs, as it was used in nearly half of the games (45.2\%). HTC Vive came in second used in almost a quarter of the games

Table 3 The inclusion criteria

\begin{tabular}{ll}
\hline Criteria & Specifics \\
\hline Publication date & $2012-2018$ \\
Type & Journal articles and conference proceedings \\
Language of publication & English \\
Education usage & Uses VR for education \\
Implementation of functionality & Present implemented artefact, not just design \\
Implementation of Mode & Single, Multiplayer \\
Implementation of Genre & Adventure, Gameplay \\
\hline
\end{tabular}


Table 4 Results of the literature search within the systematic review 2012-2018

\begin{tabular}{llll}
\hline Database (sources) & Items & Excluded & Included \\
\hline IEEE Xplore & 40 & 26 & 14 \\
ACM Digital Library & 61 & 54 & 7 \\
Google Scholar & 41 & 33 & 8 \\
ScienceDirect & 20 & 18 & 2 \\
\hline
\end{tabular}

(22.6\%). Cardboard, which is the cheapest of the VR headsets, was only used in $9.7 \%$ of the games, while under a quarter (22.6\%) of the papers we reviewed, did not specify which headsets were used as target technology.

The platforms used for the games were consistent with the headsets, given that HTC Vive and Oculus Rift DK2 are PC VR devices, $83.9 \%$ of the games were playable using a PC or MAC, while $12.9 \%$ were playable using a mobile device, which matches the Cardboard requirements (Fig. 5).

In Table 6 (technological characteristics), we show the interaction techniques and hardware used in the EVRGs. While the most basic headsets (e.g. Cardboard) provide basic VR interaction mechanisms like gaze and head movements, more advanced headsets come with more sophisticated controllers. These controllers allow the users to interact with the props in the game environment and facilitate movement. Some games provide natural user interfaces, while other task-specific games provide more advanced controllers such as steering wheels. However, it is noteworthy that traditional input devices, such as a mouse or keyboard are challenging to use with VR technology, as the latter conceals the user in a virtual environment, disallowing the visibility of the surrounding real environment. Some games have, however, suggested such input devices, which makes the gaming experience slightly inconvenient.

\section{Pedagogical characteristics}

The analysis of the games showed that more than two-thirds of the educational VR games were developed for informal learning context (Fig. 6). While the topics taught in

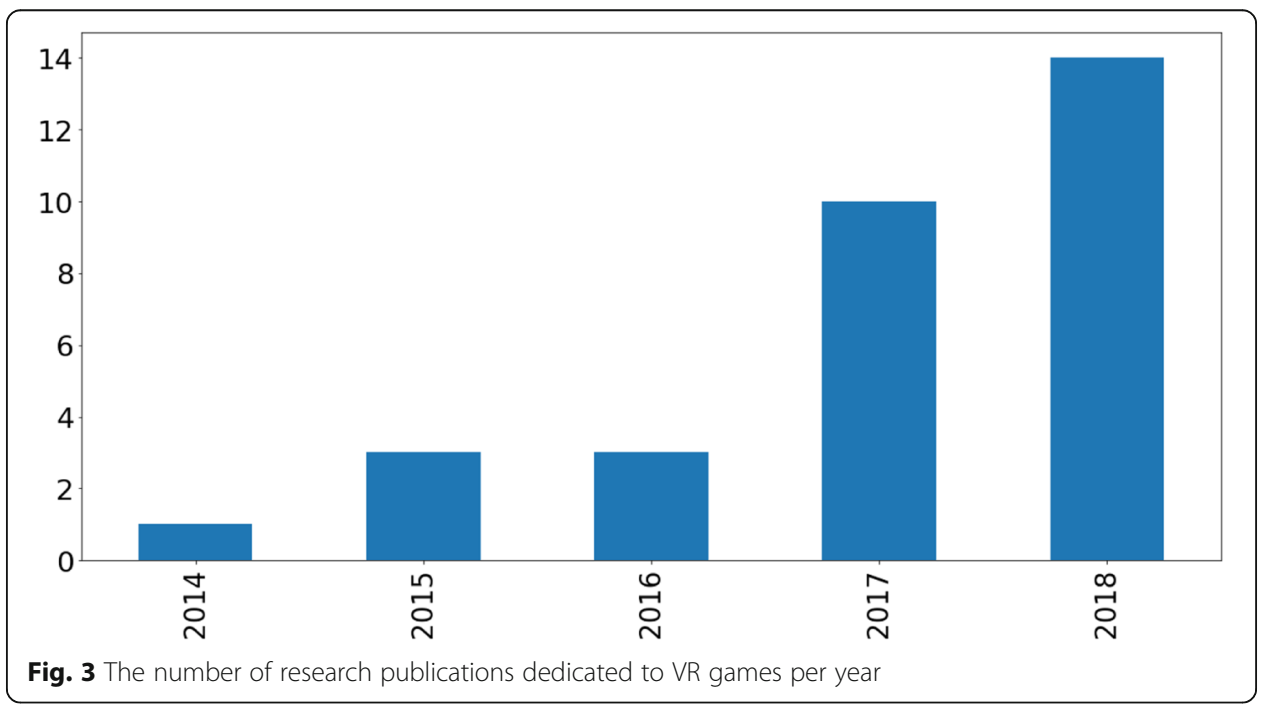


Table 5 Overview of the EVRGs

\section{ID Author's Name \& Year}

1 Tabak et al. (2017)

2 Szczurowski and Smith (2018)

3 Roberto et al. (2017)

4 Amal, Hend, and Hana (2018)

5 Bernardes, Barros, Simoes, and Castelo-Brancon (2015)

6 Byl, Süncksen, and Teistler (2018)

7 Mihajlovic, Popovic, and Brkic (2018)

8 Calvi et al. (2017)

9 Gyutae, Hojun, Sangho, Jaekwang, and Shiho (2016)

10 Chittaro and Buttussi (2015)

11 Zielke (2017)

12 Dinis, Guimarães, Carvalho, and Martins (2017)

13 Süncksen et al. (2018)

14 Zikky, Fathoni, and Firdaus (2018)

15 (Visoottiviseth, Phungphat, Puttawong, Chantaraumporn, \& Haga, 2018)

16 Sárkány (2016)

17 (Pirker, Lesjak, \& Guetl, 2017)

18 (Trombetta et al., 2017)

19 Knote, Edenhofer, and Mammen (2016)

20 Lovreglio, Gonzalez, Feng, and Sacks (2018)

\section{Country Description}

Netherlands The authors presented a VR game to improve the training of chronic pain both in the clinical and home settings.

Ireland $\quad$ A VR serious game to teach children about road safety.

Italy

A cultural heritage serious game developed to illustrate the feasibility of a framework called FRACH.

South Africa An immersive game distracting the patients from pain while performing Lower Back Problem exercises.

Spain A VR game to teach patients with autism how to use public transportation.

Germany

A serious game to teach medical students how to handle ultrasound probes and to understand spatial relationships in medical ultra sounding images.

Hungary A game that motivates users to perform neck exercises through immersion in VR.

Italy The game was developed to simulate a diving experience in a virtual environment for non-divers with the purpose to create awareness in players about a conscious sustainable behavior underwater.

South Korea The study proposes a self-training VR serious game for fire evacuation drills with concurrent tele-collaboration among avatars controlled by and synchronized with multiple users in remote places.

Italy This study proposed a head-mounted device-based immersive game for educating passengers about aviation safety that allows players to experience a serious aircraft emergency to survive it.

United States The study explored whether VR and AR technologies of America can provide a more natural interface, increase presence and facilitate the practice of empathy as compared to current medical education forms of simulation.

Portugal VR interface provides tools for students to interact with virtual building models while editing geometry and properties.

Germany In the VR environment, the user generates specific radiographs of virtual patients whereby points are awarded for image accuracy within the specified time frame and radiation exposure.

Indonesia Uses client/server architecture and brings teachers and students together into a virtual space, a specific planet.

Thailand A VR game on Android for education. It is an alternative learning material for learners to gain knowledge about network security effectively.

Germany A partly implemented serious game that uses hand gestures and eye gaze in a VR environment to help patients with dementia.

Austria Maroon VR provides several Lab stations for understanding Electromagnetism in Physics.

Great Britain A serious game for post-stroke patients. It engages patients using VR to complete their rehabilitation program.

United States This study presents an interactive simulation game to of America understand the mutual interferences of competitive (ant) species by experiencing their behavior in a novel way.

New Zealand A serious game that teaches the basics of evacuation training in the case of earthquakes in hospitals. 
Table 5 Overview of the EVRGs (Continued)

\begin{tabular}{|c|c|c|c|}
\hline ID & Author's Name \& Year & Country & Description \\
\hline 21 & $\begin{array}{l}\text { Vourvopoulos, Faria, Ponnam, and } \\
\text { Badia (2014) }\end{array}$ & $\begin{array}{l}\text { United States } \\
\text { of America }\end{array}$ & $\begin{array}{l}\text { This paper presents the design, implementation, and } \\
\text { validation of RehabCity, an online game designed for } \\
\text { the rehabilitation of cognitive deficits through a } \\
\text { gamified approach on activities of daily living. }\end{array}$ \\
\hline 22 & $\begin{array}{l}\text { Bryan, Campbell, and Mangina } \\
\text { (2018) }\end{array}$ & Ireland & $\begin{array}{l}\text { A VR game that allows students to learn about various } \\
\text { locations in the world using Google Street View. }\end{array}$ \\
\hline 23 & Shahab (2017) & Ireland & $\begin{array}{l}\text { This paper presents a novel VR setup with the ability } \\
\text { to teach music to children with autism as well as to } \\
\text { perform an automatic assessment of their behaviors. } \\
\text { This setup contains Social Virtual Reality Robots (V2Rs) } \\
\text { and virtual musical instruments (i.e. xylophone and } \\
\text { drum). }\end{array}$ \\
\hline 24 & Likitweerawong and Palee (2018) & Thailand & $\begin{array}{l}\text { A serious game that simulates a car environment and } \\
\text { allows participants to test their driving skills. }\end{array}$ \\
\hline 25 & $\begin{array}{l}\text { Chin, Kamsani, Zhong, Cui, and } \\
\text { Yang (2018) }\end{array}$ & China & $\begin{array}{l}\text { A VR game that allows training on Remotely Operated } \\
\text { Vehicles. }\end{array}$ \\
\hline 26 & Moldoveanu (2017) & Romania & $\begin{array}{l}\text { The paper proposes a training strategy for a sensory } \\
\text { substitution device to improve the ability of visually } \\
\text { impaired people to be autonomous thus, to increase } \\
\text { the quality of their lives. }\end{array}$ \\
\hline 27 & Chiu (2017) & Taiwan & $\begin{array}{l}\text { In this study, a VR game was developed for elementary } \\
\text { school students to learn about Taiwan's aboriginal } \\
\text { tribe's native languages. }\end{array}$ \\
\hline 28 & $\begin{array}{l}\text { Hafsia, Monacelli, and Martin } \\
\text { (2018) }\end{array}$ & France & $\begin{array}{l}\text { A VR game to teach construction workers about safety } \\
\text { in the work environment. }\end{array}$ \\
\hline 29 & $\begin{array}{l}\text { Diez, Andoni, Aitor, and Oyarzun } \\
\text { (2016) }\end{array}$ & Spain & $\begin{array}{l}\text { The research presents an interactive application for } \\
\text { training experts on the prevention of occupational } \\
\text { hazards such as fire safety in buildings. }\end{array}$ \\
\hline 30 & Puttawong et al. (2017) & Japan & $\begin{array}{l}\text { The paper explores the use of VR technology to } \\
\text { develop a fantasy RPG called VRFiWall that teaches } \\
\text { computer security. }\end{array}$ \\
\hline 31 & Alrehaili (2018) & Canada & $\begin{array}{l}\text { This research project discusses the design, } \\
\text { development and evaluation of a RPG that teaches } \\
\text { children about the lives of bees. }\end{array}$ \\
\hline
\end{tabular}

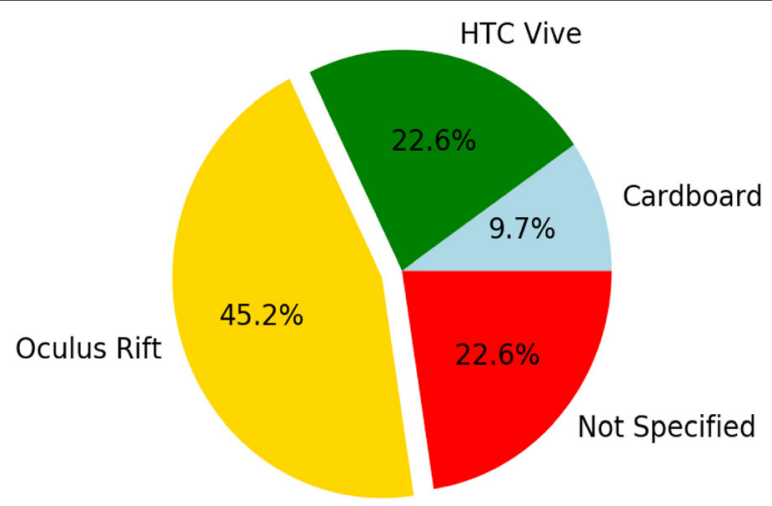

Fig. 4 Headsets breakdown in surveyed literature 


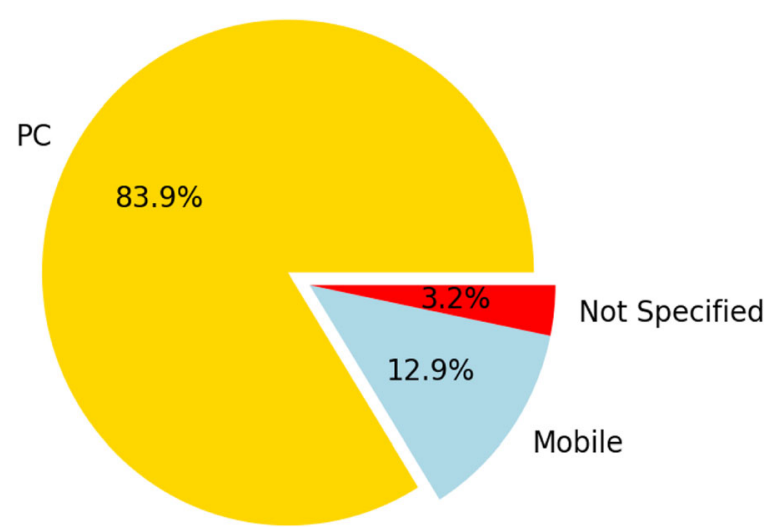

Fig. 5 The distribution of the platforms in the literature within the SR

Table 6 Technological Characteristics of EVRGs

\begin{tabular}{|c|c|c|c|c|}
\hline ID & Author's Name \& Year & Platform & VR Headset & Interaction \\
\hline 1 & Tabak et al. (2017) & PC & Not specified & Gaze \\
\hline 2 & Szczurowski and Smith (2018) & PC & Oculus Rift & Head movement, gaze \\
\hline 3 & Roberto et al. (2017) & PC & Oculus Rift & Head movement \\
\hline 4 & Alazba, Al-Khalifa, and AlSobayel (2018) & Mobile & Cardboard & Physical movements \\
\hline 5 & Bernardes et al. (2015) & PC & Oculus Rift & - \\
\hline 6 & Byl et al. (2018) & PC & HTC Vive & Controllers \\
\hline 7 & Mihajlovic et al. (2018) & PC & Oculus Rift & Head movement \\
\hline 8 & Calvi et al. (2017) & PC & HTC Vive & Controllers \\
\hline 9 & Gyutae et al. (2016) & PC & Not Specified & Wearable sensors, body movements \\
\hline 10 & Chittaro and Buttussi (2015) & PC & Oculus Rift & Head movement, Kinect \\
\hline 11 & Zielke (2017) & PC & Oculus Rift & Natural user interface (NUI) \\
\hline 12 & Dinis et al. (2017) & PC & Not Specified & Game controller, NUI \\
\hline 13 & Süncksen et al. (2018) & PC & HTC Vive & Controllers \\
\hline 14 & Zikky et al. (2018) & PC & Oculus Rift & Leap motion \\
\hline 15 & (Visoottiviseth et al., 2018) & Mobile & Not specified & Gaze \\
\hline 16 & Sárkány (2016) & PC & Oculus Rift & Leap motion, gaze \\
\hline 17 & (Pirker et al., 2017) & PC & HTC Vive & Teleporting and keypad controller \\
\hline 18 & (Trombetta et al., 2017) & PC & Oculus Rift & Kinect \\
\hline 19 & Knote et al. (2016) & PC & Oculus Rift & Gaze \\
\hline 20 & Lovreglio et al. (2018) & PC & HTC Vive & Controllers, vibrating seats \\
\hline 21 & Vourvopoulos et al. (2014) & PC & Webcam & Gaze \\
\hline 22 & Bryan et al. (2018) & PC & HTC Vive & Controllers \\
\hline 23 & (Shahab, 2017) & PC & Oculus & Head movement \\
\hline 24 & Likitweerawong and Palee (2018) & PC & Oculus Rift & Steering wheel joystick \\
\hline 25 & Chin et al. (2018) & PC & Not specified & Joystick, keyboard \\
\hline 26 & Moldoveanu (2017) & - & Not Specified & Players body orientation \\
\hline 27 & Chiu (2017) & Mobile & Cardboard & Gaze \\
\hline 28 & Hafsia et al. (2018) & PC & HTC Vive & Controllers \\
\hline 29 & Diez et al. (2016) & PC & Oculus Rift & Controller - gesture movement \\
\hline 30 & VRFiWall (2017) & Mobile & VR Headsets & Cardboard, gestures, pointing \\
\hline 31 & Alrehaili (2018) & PC & Oculus Rift & Head movement, PC keyboard \\
\hline
\end{tabular}




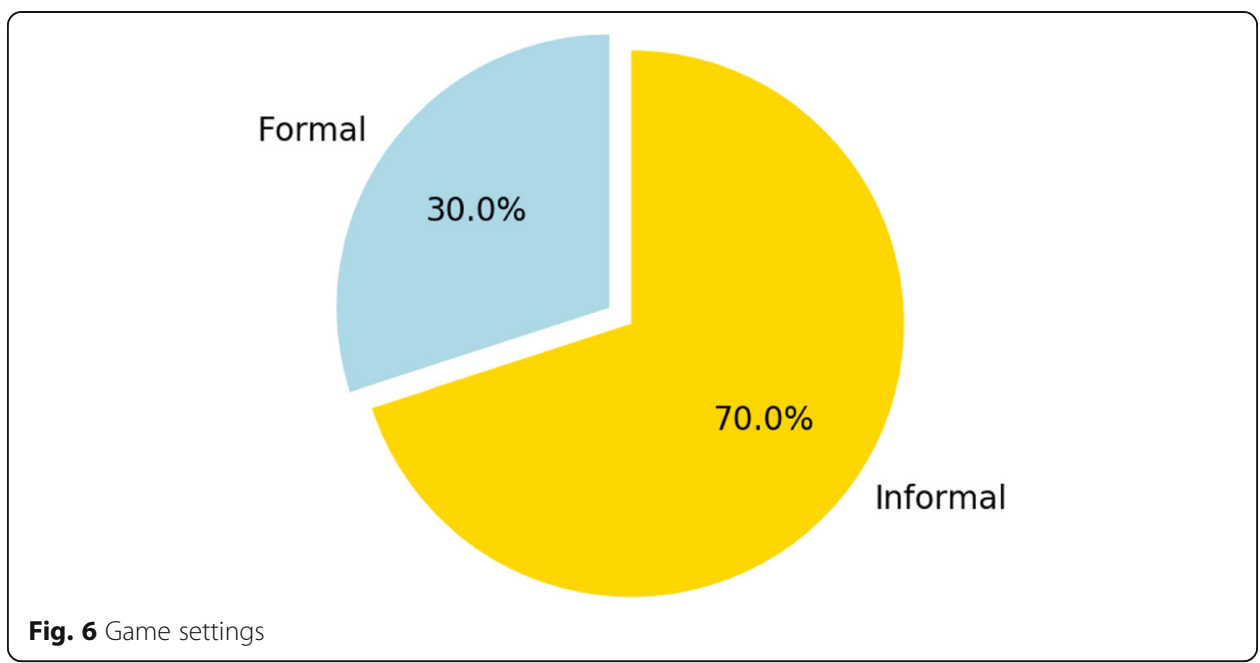

the analyzed games were of great variety, we tried to group them under specific themes, to understand which of the tasks or learning goals were deemed VR-appropriate by the researchers. For instance, one-third of the games targeted teaching healthcare-related topics, while a quarter of the games aimed at introducing, training, or enforcing safety measures in various environments (e.g., construction sites, hospitals, or roads). Topics such as biology, physics or astronomy represent a tenth of the surveyed games (represented in Fig. 7 as natural sciences). While topics like language learning, geography, and civil engineering, received minimum interest with one VR game each.

The target audience of the EVRGs depended on the desired learning outcomes. Additionally, the VR games were developed for all levels of formal education, from K-12 to tertiary education students, as well as for lifelong learners who need to acquire some skills to deal with specific health conditions, as illustrated in Table 7.

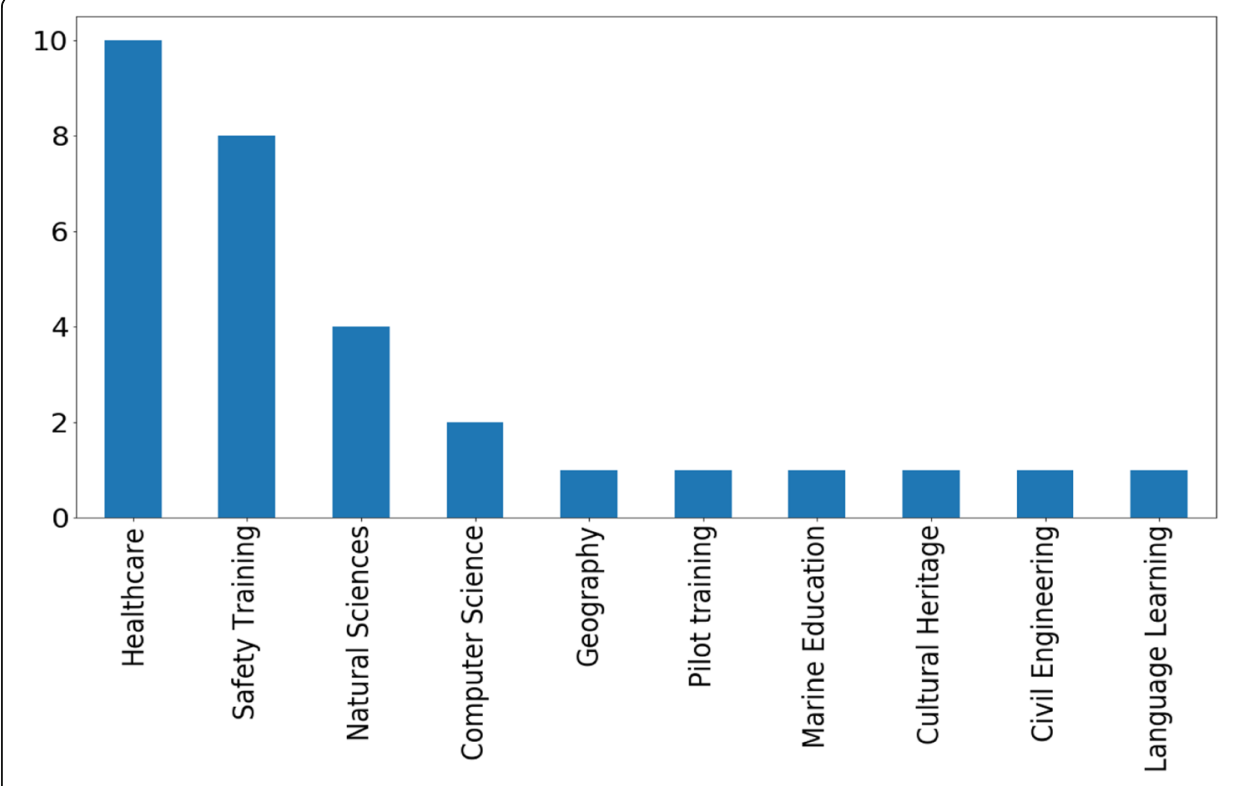

Fig. 7 The topics taught using VR educational games 
Table 7 Pedagogical characteristics of EVRGs

\begin{tabular}{|c|c|c|c|c|c|c|}
\hline ID & $\begin{array}{l}\text { Author's Name } \\
\text { \& Year }\end{array}$ & Subject & Learner & Setting & $\begin{array}{l}\text { Research } \\
\text { Method }\end{array}$ & Evaluation \\
\hline 1 & $\begin{array}{l}\text { Tabak et al. } \\
(2017)\end{array}$ & Healthcare & Adults & Informal & Qualitative & $\begin{array}{l}\text { Think-aloud protocol } \\
\text { \& interview }\end{array}$ \\
\hline 2 & $\begin{array}{l}\text { Szczurowski and } \\
\text { Smith (2018) }\end{array}$ & Road Safety & Children & Informal & Qualitative & Usability test \\
\hline 3 & $\begin{array}{l}\text { Roberto et al. } \\
\text { (2017) }\end{array}$ & $\begin{array}{l}\text { Cultural } \\
\text { heritage }\end{array}$ & $\begin{array}{l}\text { students, teachers, and } \\
\text { employers }\end{array}$ & Formal & $\begin{array}{l}\text { Mixed } \\
\text { method }\end{array}$ & Survey \\
\hline 4 & $\begin{array}{l}\text { Alazba et al. } \\
\text { (2018) }\end{array}$ & $\begin{array}{l}\text { Exercise } \\
\text { game }\end{array}$ & $\begin{array}{l}\text { People with non- } \\
\text { specific chronic low } \\
\text { back pain }\end{array}$ & Informal & - & - \\
\hline 5 & $\begin{array}{l}\text { Bernardes et al. } \\
\text { (2015) }\end{array}$ & Road Safety & ASD patients & Informal & Quantitative & Interface evaluation \\
\hline 6 & Byl et al. (2018) & Medical & Medical students & Formal & $\begin{array}{l}\text { Mixed } \\
\text { Methods }\end{array}$ & $\begin{array}{l}\text { Think-aloud protocol } \\
\text { \& observation }\end{array}$ \\
\hline 7 & $\begin{array}{l}\text { Mihajlovic et al. } \\
\text { (2018) }\end{array}$ & Healthcare & Patients with neck pain & Informal & Quantitative & User study \\
\hline 8 & Calvi et al. (2017) & $\begin{array}{l}\text { Marine } \\
\text { Education }\end{array}$ & Students \& employed & Informal & $\begin{array}{l}\text { Presence } \\
\text { questionnaire }\end{array}$ & Questionnaire \\
\hline 9 & $\begin{array}{l}\text { Gyutae et al. } \\
\text { (2016) }\end{array}$ & $\begin{array}{l}\text { Fire } \\
\text { evacuation } \\
\text { drill }\end{array}$ & Students \& employed & Informal & Quantitative & $\begin{array}{l}\text { User experience } \\
\text { survey }\end{array}$ \\
\hline 10 & $\begin{array}{l}\text { Chittaro and } \\
\text { Buttussi (2015) }\end{array}$ & Safety & Students \& employed & Informal & $\begin{array}{l}\text { Knowledge } \\
\text { test }\end{array}$ & $\begin{array}{l}\text { Between-groups } \\
\text { study }\end{array}$ \\
\hline 11 & Zielke (2017) & $\begin{array}{l}\text { Medical } \\
\text { Training }\end{array}$ & Medical students & Formal & - & No \\
\hline 12 & $\begin{array}{l}\text { Dinis et al. } \\
\text { (2017) }\end{array}$ & $\begin{array}{l}\text { Civil } \\
\text { Engineering }\end{array}$ & Pre-university students & Formal & Qualitative & $\begin{array}{l}\text { Case studies \& } \\
\text { experience survey }\end{array}$ \\
\hline 13 & $\begin{array}{l}\text { Süncksen et al. } \\
\text { (2018) }\end{array}$ & $\begin{array}{l}\text { Medical } \\
\text { Training }\end{array}$ & Not specified & Formal & $\begin{array}{l}\text { Mixed } \\
\text { Methods }\end{array}$ & Usability survey \\
\hline 14 & $\begin{array}{l}\text { Zikky et al. } \\
\text { (2018) }\end{array}$ & Astronomy & Students & Formal & - & Questionnaire \\
\hline 15 & $\begin{array}{l}\text { (Visoottiviseth } \\
\text { et al., 2018) }\end{array}$ & $\begin{array}{l}\text { Computer } \\
\text { Networks }\end{array}$ & University Students & Informal & Qualitative & User interface survey \\
\hline 16 & Sárkány (2016) & Healthcare & Dementia Patients & Informal & Quantitative & \\
\hline 17 & $\begin{array}{l}\text { (Pirker et al., } \\
\text { 2017) }\end{array}$ & Physics & Students \& employed & Formal & $\begin{array}{l}\text { Mixed } \\
\text { Methods }\end{array}$ & $\begin{array}{l}\text { Questionnaire \& } \\
\text { interview }\end{array}$ \\
\hline 18 & $\begin{array}{l}\text { (Trombetta et al., } \\
\text { 2017) }\end{array}$ & $\begin{array}{l}\text { Healthcare- } \\
\text { Rehabilitation }\end{array}$ & Post-stroke patients & Informal & Quantitative & Questionnaire \\
\hline 19 & $\begin{array}{l}\text { Knote et al. } \\
(2016)\end{array}$ & Biology & Not specified & Informal & Not defined & $\begin{array}{l}\text { Preliminary } \\
\text { evaluation }\end{array}$ \\
\hline 20 & $\begin{array}{l}\text { Lovreglio et al. } \\
\text { (2018) }\end{array}$ & $\begin{array}{l}\text { Evacuation } \\
\text { Training }\end{array}$ & General Public & Informal & Qualitative & Questionnaire \\
\hline 21 & $\begin{array}{l}\text { Vourvopoulos } \\
\text { et al. (2014) }\end{array}$ & Healthcare & $\begin{array}{l}\text { patients with brain } \\
\text { lesion }\end{array}$ & Informal & $\begin{array}{l}\text { Mixed } \\
\text { Methods }\end{array}$ & $\begin{array}{l}\text { Experiment and } \\
\text { questionnaire }\end{array}$ \\
\hline 22 & $\begin{array}{l}\text { Bryan et al. } \\
\text { (2018) }\end{array}$ & Geography & Educators and students & Formal & Quantitative & Questionnaire \\
\hline 23 & (Shahab, 2017) & Healthcare & Children with Autism & Informal & Quantitative & Questionnaire \\
\hline 24 & $\begin{array}{l}\text { Likitweerawong } \\
\text { and Palee (2018) }\end{array}$ & Road Safety & Adults & Informal & Quantitative & User experience \\
\hline 25 & Chin et al. (2018) & Pilot training & Adults & Informal & Quantitative & Simulation \\
\hline 26 & $\begin{array}{l}\text { Moldoveanu } \\
\text { (2017) }\end{array}$ & Healthcare & visually impaired & Informal & Not explicit & Preliminary testing \\
\hline 27 & Chiu (2017) & $\begin{array}{l}\text { Language } \\
\text { Learning }\end{array}$ & $\begin{array}{l}\text { Elementary school } \\
\text { learners }\end{array}$ & Informal & Quantitative & Pre-post test \\
\hline
\end{tabular}


Table 7 Pedagogical characteristics of EVRGs (Continued)

\begin{tabular}{|c|c|c|c|c|c|c|}
\hline ID & $\begin{array}{l}\text { Author's Name } \\
\text { \& Year }\end{array}$ & Subject & Learner & Setting & $\begin{array}{l}\text { Research } \\
\text { Method }\end{array}$ & Evaluation \\
\hline 28 & $\begin{array}{l}\text { Hafsia et al. } \\
\text { (2018) }\end{array}$ & $\begin{array}{l}\text { Training } \\
\text { application }\end{array}$ & Construction workers & Informal & Qualitative & User opinion \\
\hline 29 & Diez et al. (2016) & $\begin{array}{l}\text { Fire safety } \\
\text { training }\end{array}$ & Not specified & Informal & $\begin{array}{l}\text { Testing } \\
\text { scenario }\end{array}$ & Preliminary test \\
\hline 30 & $\begin{array}{l}\text { Puttawong et al. } \\
\text { (2017) }\end{array}$ & $\begin{array}{l}\text { Computer } \\
\text { Security }\end{array}$ & University Students & Formal & - & No \\
\hline 31 & Alrehaili (2018) & Biology & Children & Informal & Quantitative & $\begin{array}{l}\text { Knowledge test and } \\
\text { feedback } \\
\text { questionnaire }\end{array}$ \\
\hline
\end{tabular}

\section{Gaming characteristics of EVRGs}

The 31 EVRGs reviewed in this paper differ significantly in the player roles suggested to their users but are mainly dependent on the educational purpose of the tool. Most of the games suggest player roles that are adequate for the tasks the user is being prepared for, in environments similar to those that they will be working on (see Table 8 for several aspects of gaming characteristics). This shows the power of VR in providing learners with a preview of working activities and conditions.

VR facilitates collaborative learning, where many learners can be together in the same virtual world to execute some learning tasks. Only five EVRGs incorporated such a feature in their designs, while 26 games decided to allow only single-player mode. Gameplay-wise, most games suggest the user moves through the virtual world and executes tasks similar to the real-world tasks they are being prepared for, and so games genres like puzzles are quasi-inexistent in the game set that we have reviewed. This study has found that the VR games present the content to be taught as a series of entertaining challenges to the learner in a virtual environment.

\section{Discussion}

\section{General overview}

The study revealed that the number of articles or literature on emerging VR systems has been increasing since 2012, which indicates the interest VR has gained since its spread in late 2012. The study also revealed many educational topics in which VR has already been applied. A general emphasis was placed on healthcare education by VR researchers, along with a variety of other topics such as biology, computer science, astronomy, and fire training (Sárkány, 2016; Süncksen et al., 2018). VR has the potential to allow users to experience environments that are otherwise inaccessible in a very realistic way. It allows training in environments that would otherwise be hazardous for learners to train in, as is the case for fire training (Diez et al., 2016). It also allows learners to simulate training with expensive hardware on a risk-free yet realistic environment. Despite these affordances and the application of VR unraveled by this study, there appears to be a lack of research on the use of VR for language learning, failing to benefit from the technology in simulating social interactions, which are very efficient in helping learners to practice their language skills effectively.

Another key finding of this research is the absence of any VR educational games on the African continent. While North and South America, Europe, Asia and Australia 
Table 8 Gaming characteristics of EVRGs

\begin{tabular}{|c|c|c|c|c|c|}
\hline ID & $\begin{array}{l}\text { Author's Name \& } \\
\text { Year }\end{array}$ & Player Role & Theme & Mode & Gameplay \& Goal \\
\hline 1 & Tabak et al. (2017) & Cook & Home environment & $\begin{array}{l}\text { Single } \\
\text { player }\end{array}$ & Simulation game \\
\hline 2 & $\begin{array}{l}\text { Szczurowski and } \\
\text { Smith (2018) }\end{array}$ & Pedestrian & Street, roads & $\begin{array}{l}\text { Single } \\
\text { player }\end{array}$ & Manage, RPG \\
\hline 3 & Roberto et al. (2017) & Archeologist & Archaeological site & Multiplayers & $\begin{array}{l}\text { Serious game, } \\
\text { storytelling, and puzzles }\end{array}$ \\
\hline 4 & Alazba et al. (2018) & Goldfish & Sea/underwater & $\begin{array}{l}\text { Single } \\
\text { player }\end{array}$ & $\begin{array}{l}\text { Simulation (exercise } \\
\text { game) }\end{array}$ \\
\hline 5 & $\begin{array}{l}\text { Bernardes et al. } \\
\text { (2015) }\end{array}$ & Human/generic & City environment & $\begin{array}{l}\text { Single } \\
\text { player }\end{array}$ & Simulation \\
\hline 6 & Byl et al. (2018) & Medical Worker & Hospital & $\begin{array}{l}\text { Single } \\
\text { player }\end{array}$ & Select, simulation \\
\hline 7 & $\begin{array}{l}\text { Mihajlovic et al. } \\
\text { (2018) }\end{array}$ & Human/Generic & Sky & $\begin{array}{l}\text { Single } \\
\text { player }\end{array}$ & $\begin{array}{l}\text { User tracks moving } \\
\text { objects in sky }\end{array}$ \\
\hline 8 & Calvi et al. (2017) & $\begin{array}{l}\text { Driver of a diving } \\
\text { machine }\end{array}$ & Sea/underwater & Single user & VR dive simulation \\
\hline 9 & Gyutae et al. (2016) & Human/generic & Building on fire & $\begin{array}{l}\text { Single } \\
\text { player }\end{array}$ & $\begin{array}{l}\text { Self-training VR for fire } \\
\text { evacuation }\end{array}$ \\
\hline 10 & $\begin{array}{l}\text { Chittaro and Buttussi } \\
(2015)\end{array}$ & Passenger & Plane environment & $\begin{array}{l}\text { Single } \\
\text { player }\end{array}$ & VR Simulation \\
\hline 11 & Zielke (2017) & Medical Worker & Hospital & $\begin{array}{l}\text { Single } \\
\text { player }\end{array}$ & Simulation \\
\hline 12 & Dinis et al. (2017) & Civil Engineer & $\begin{array}{l}\text { Building internal and } \\
\text { external }\end{array}$ & $\begin{array}{l}\text { Single } \\
\text { player }\end{array}$ & Simulation \\
\hline 13 & Süncksen et al. (2018) & Medical Worker & Operating room & $\begin{array}{l}\text { Single } \\
\text { Player }\end{array}$ & Select, Simulation \\
\hline 14 & Zikky et al. (2018) & Student & Space/planets/stars & Multiplayer & Select, Simulation \\
\hline 15 & $\begin{array}{l}\text { (Visoottiviseth et al., } \\
\text { 2018) }\end{array}$ & Human generic & Forest, city & Single & Educational \\
\hline 16 & Sárkány (2016) & Human/Generic & Food table & $\begin{array}{l}\text { Single } \\
\text { Player }\end{array}$ & Build, select, RPG \\
\hline 17 & (Pirker et al., 2017) & Physicist & Physics lab & Multiplayer & Simulation \\
\hline 18 & $\begin{array}{l}\text { (Trombetta et al., } \\
\text { 2017) }\end{array}$ & $\begin{array}{l}\text { Person doing } \\
\text { physical exercise }\end{array}$ & Beach & $\begin{array}{l}\text { Single } \\
\text { Player }\end{array}$ & Exergame \\
\hline 19 & Knote et al. (2016) & Biologist & Nature & $\begin{array}{l}\text { Single } \\
\text { player }\end{array}$ & Simulation \\
\hline 20 & Lovreglio et al. (2018) & $\begin{array}{l}\text { Visitor or worker in } \\
\text { hospital }\end{array}$ & Hospital & $\begin{array}{l}\text { Single } \\
\text { Player }\end{array}$ & $\begin{array}{l}\text { Simulation, manage, } \\
\text { select, avoid }\end{array}$ \\
\hline 21 & $\begin{array}{l}\text { Vourvopoulos et al. } \\
\text { (2014) }\end{array}$ & Human/Generic & City environment & $\begin{array}{l}\text { Single } \\
\text { player }\end{array}$ & Serious game \\
\hline 22 & Bryan et al. (2018) & Explorer & $\begin{array}{l}\text { Various real-world } \\
\text { locations }\end{array}$ & $\begin{array}{l}\text { Single } \\
\text { player }\end{array}$ & Real-world environment \\
\hline 23 & Shahab (2017) & Robot & $\begin{array}{l}\text { Room with musical } \\
\text { instruments }\end{array}$ & $\begin{array}{l}\text { Single } \\
\text { player }\end{array}$ & Play musical instruments \\
\hline 24 & $\begin{array}{l}\text { Likitweerawong and } \\
\text { Palee (2018) }\end{array}$ & Driver & Inside of a car & $\begin{array}{l}\text { Single } \\
\text { Player }\end{array}$ & Move, Simulation \\
\hline 25 & Chin et al. (2018) & Driver & Nature & $\begin{array}{l}\text { Single } \\
\text { Player }\end{array}$ & Move, Simulation \\
\hline 26 & Moldoveanu (2017) & Human/generic & Street/home & $\begin{array}{l}\text { Single } \\
\text { player }\end{array}$ & Simulation \\
\hline 27 & Chiu (2017) & Customer & Restaurant & $\begin{array}{l}\text { Single } \\
\text { player }\end{array}$ & Educational \\
\hline
\end{tabular}


Table 8 Gaming characteristics of EVRGs (Continued)

\begin{tabular}{|c|c|c|c|c|c|}
\hline ID & $\begin{array}{l}\text { Author's Name \& } \\
\text { Year }\end{array}$ & Player Role & Theme & Mode & Gameplay \& Goal \\
\hline 28 & Hafsia et al. (2018) & $\begin{array}{l}\text { Construction } \\
\text { Worker }\end{array}$ & Construction site & $\begin{array}{l}\text { Single } \\
\text { Player }\end{array}$ & Build, avoid, Simulation \\
\hline 29 & Diez et al. (2016) & Fireman & Building on fire & Multiplayer & Training fire wardens \\
\hline 30 & $\begin{array}{l}\text { Puttawong et al. } \\
\text { (2017) }\end{array}$ & Human/Generic & Forest/nature & $\begin{array}{l}\text { Single } \\
\text { player }\end{array}$ & Educational \\
\hline 31 & Alrehaili (2018) & Bee & Nature/hive & $\begin{array}{l}\text { Single } \\
\text { Player }\end{array}$ & $\begin{array}{l}\text { Manage, build, select, } \\
\text { avoid, RPG }\end{array}$ \\
\hline
\end{tabular}

participated in developing EVRGs. The cost of technology seems to affect African countries from benefiting from this promising technology. One solution is to rely on affordable headsets supported by Google Cardboard (Bouali et al., 2019). Still, such headsets suffer from the lack of appropriate interaction hardware that allows users to traverse and interact with the virtual world using only gaze and head movement. Such limitation causes Cardboard-related research to engineer games that require minimum interaction while preserving the targeted learning outcomes.

\section{Technology and gaming}

Despite Cardboard being the cheapest VR device, it is the least used technology in the surveyed literature, ranking even lower than the expensive HTC Vive. This raises some questions on the level of adoption of some educational games in real educational contexts, which is not the focus of our study. Nevertheless, the study shows that various games have adopted the use of the Oculus Rift VR, despite being more expensive than Cardboard headsets. Consequently, headsets are not the only problem in VR adoption. This study reveals that interaction is also an issue. In our analysis, we found that most of the games rely on gaze as an interaction mechanism, but this is hardly ever complemented with a natural user interface or interfaces, which facilitate interactions in VR worlds, resulting in the difficulty of using other input devices like keyboards.

Games that target teaching specific skills, such as diving or driving, require more advanced input devices, like Kinect to input body movement or a steering wheel to provide a life-like controller to a vehicle in the virtual world (Calvi et al., 2017; Likitweerawong \& Palee, 2018). However, this incurs that such technology can only be afforded by a handful of users, presenting a stumbling block in the adoption of VR games in real-world contexts.

Regarding gaming, most of the gaming environments and contexts were dependent on the real-world context for which the learner is being prepared. This helps in the learning process of the user as it provides him/her with tailored environments that mimic the real world to a higher level of detail. The study also reveals that most of the games developed, allowed only for a single-player mode, failing to benefit from VR's ability to connect learners in virtual worlds. The dominant game genre in the literature is Role Playing Game (RPG), which is adequate given that the learner impersonates the roles they are being trained for in the virtual world. 


\section{Pedagogy}

The concept of applying digital technology to build a virtual, physical/virtual or hybrid learning environment in which a student experiences a form of play, has emerged over the years and is now gaining acceptance. The puzzle here is that despite the wide variety of VR games developed for different fields (education, healthcare, business, climate, energy, industrial, and financial) only a handful of the games focused on education. Thus, begging the question of why EVRGs have not been widely adopted in mainstream education? Considering the interactive, immersive, and multi-sensory nature of VR, coupled with its growing popularity amongst researchers in psychology, aviation, and cognitive neuroscience, we had expected that even more EVRGs could have been developed and that the technology should have been widely adopted (Alexander et al., 2019). However, there are many reasons for the lack of adoption of EVRGs in mainstream education. One reason is that people tend not to consider VR as a mainstream technology. They perceived that the hype around the technology would lose popularity and be replaced by the reality of the time, in what was called the 'trough of disillusion' (Linden \& Fenn, 2003). Additionally, there seems to be a lack of know-how by learning technologists and experts on how to design learning solutions with VR. Furthermore, the costs of implementing EVRG for large-scale adoption across educational curricula constitute a limiting factor for adoption in mainstream education (Alexander et al., 2019) and health-related issues.

Christou (2010) states that the three categories of formal and informal educational application areas of VR are used to improve core curriculum subjects such as the applications for edutainment, demonstrations, cultural heritage and museum experiences, as well as an application for training. Our analysis of the pedagogical contributions of EVRGs indicated a considerable variation among the subjects that were implemented. For example, the trend of EVRGs in this study showed that $32 \%$ of the applications were developed to support medical education. In contrast, only $3 \%$ was implemented to support subjects that involve the concretization of abstract concepts such as physics and geography.

Although the learners in these studies balanced well amongst children, youth and adult learners, there are obvious variations amongst the type of learners about the kind of EVRGs. For example, most learners could have medical conditions such as patients with neck or back pain, dementia, autism spectrum disorders, post-stroke conditions, brain lesions, and visual impairment. Translating clinical procedure into EVRGs to facilitate learning and future implementation of the procedure by caregivers and patients constitute the main interest in developing medical EVRGs (Heuven et al., 2017; Mihajlovic et al., 2018). Simulating the medical procedure offer motivation, engagement, and positive learning experience among EVRGs users (Trombetta et al., 2017). Having examined an essential pedagogical attribute, of the context of the learner in this study, we noticed that the learning context for most EVRGs falls within the informal settings. As several EVRGs are developed to provide particular training solutions to the user, the informality of the setting tends to overshadow the necessity of a classroom environment (formal setting).

\section{Limitations of this study}

The limitations of this study include: 
i. The study focused on EVRGs in the educational domain without considering other uses in other facets within the gaming industry.

ii. The study did not consider cross-cultural usage of the EVRGs, such as articles published in languages other than English.

\section{Conclusion}

Several studies have shown that the most critical value that VR adds to existing technology is the sense of immersivity in a virtual world built around the user. In education, it is theoretically crucial for learners to experience real-world scenarios from a firstperson perspective compared to traditional two-dimensional (2D) screens which usually offer learners the chance to traverse the world from a third-person perspective, usually using an avatar. "Virtual Reality" as a concept, reveals some ambiguity as some of the research we surveyed referred to it as desktop VR, while others use the term to mean immersive VR. However, the inclusion criteria we developed focused on working on systems that immerse users into a virtual world rather than research that suggests a virtual world on a desktop screen.

Virtual reality, augmented reality, and mixed reality are rapidly evolving phenomena in the educational landscape. Literature has shown the positive impacts that these adaptive and immersive technologies could have on students learning when applied in the gaming contexts. The essence of this study was to contribute new knowledge using analysis and synthesis of research articles that focused on the EVRGs in different contexts. The study explores the trends of EVRGs and relevant characteristic attributes that make effective learning such as technology, pedagogy and gaming. Besides, this study considers the learning content and the technology to be the critical aspects of the transactions that go with the teaching and learning process in terms of the pedagogy.

Moreover, the review focused on the application of VR as a gaming technology, with the learner fully immersed in the environment. In the final analysis, the review exposed a growing trend of research in EVRGs studies since 2012 to 2018, while also revealing the application of VR in the sciences, healthcare and technology education spheres having the most significant attention. The mainstream education and arts (such as languages) gained the least interest of educators using VR. This scenario offers the opportunity for further research in the educational contexts with emphasis on the arts and humanities disciplines. It is therefore pertinent that through this systematic review, technology-mediated learning will be enhanced when there is a clear understanding of the trends concerning its application in the different domains of learning.

\footnotetext{
Abbreviations

ICT: Information and Communication Technology; VR: Virtual Reality; AR: Augmented Reality; MR: Mixed Reality; EVRGs: Educational Virtual Reality Games; RPG: Role Playing Game; 2D: Two-Dimension; 3D: Three-Dimension; PC: Personal Computer; NUI: Natural User Interface; HMD: Head Mounted Device; UEF: University of Eastern Finland; MS Excel: Microsoft Excel; ACM: Association for Computing Machinery; IEEE: Institute of Electrical and Electronics Engineers 
author was involved in the drafting of the result and discussion section of the work and revising it critically for important intellectual content. The third author made substantial contributions and participated in data searching in ScienceDirect database, collection and analysis, writing and reviewing the article. The author was involved in the drafting of some aspect of the literature review section of the work and revising it critically for important intellectual content. The fourth author made substantial contributions to the design of the literature review process. The author was involved in the acquisition of data from Google scholar database, analysis, and interpretation of data for the work. The author was involved in the drafting of the result and discussion section of the work, proofreading, and revising it critically for important intellectual content. The fifth author made substantial contributions and reviewed articles related to ACM database within the scope of the systematic review. The author was involved in drafting some aspects of the literature review section. The author was also responsible for analysis, and interpretation of data for the work and edited some portions of the manuscript and drafted the conclusion as well as the abstract. The sixth author made substantial contributions and participated in data searching in IEEE database, collection and analysis, and reviewing the article. The author was involved in the drafting of some aspects of the literature review section of the work and revising it critically for important intellectual content. General note: It is important to mention here that the manuscript went through circles of reading, proofreading and editing by all the authors. The authors' read and approved the final manuscript.

\section{Funding}

Not applicable.

Availability of data and materials

Not applicable.

\section{Competing interests}

No competing interests.

\section{Author details}

${ }^{1}$ University of Eastern Finland, School of Computing, Joensuu, Finland. ${ }^{2}$ Faculty of Electrical Engineering, Mathematics and Computer Science, University of Twente, Enschede, NB 7522, The Netherlands. ${ }^{3}$ Department of Education, University of Oslo, Oslo, Norway. ${ }^{4}$ University of the Witwatersrand, Johannesburg, South Africa. ${ }^{5}$ Usmanu Danfodiyo University, Sokoto, Nigeria. ${ }^{6}$ Crown Hill University, Eiyekorin, llorin, Kwara State, Nigeria.

Received: 29 July 2020 Accepted: 6 October 2020

Published online: 19 October 2020

\section{References}

Aggarwal, R., Black, S. A., Hance, J. R., Darzi, A., \& Cheshire, N. J. W. (2006). Virtual reality simulation training can improve inexperienced surgeons' endovascular skills. European Journal of Vascular and Endovascular Surgery, 31(6), 588-593.

Alazba, A., Al-Khalifa, H., \& AlSobayel, H. (2018). A proposed game for promoting physical activities among people with low back pain using virtual reality. In Proc. 11th PErvasive technologies related to assistive environments conference (PETRA '18), (pp. 141-144). New York: ACM. https://doi.org/10.1145/3197768.3197780.

Alexander, B., Ashford-Rowe, K., Barajas-Muphy, N., Dobbin, G., Knott, J., \& Mccormack, M. (2019). Educase horizon report. Louisville: EDUCAUSE, Higher Education Edition https://ibrary.educause.edu/resources/2019/4/2019-horizon-report.

Alrehaili, E. A. (2018). A Virtual reality role-playing serious game for experiential learning. (Master thesis), University of Ottawa. https://doi.org/10.20381/ruor-22159.

Amal, A., Hend, A., \& Hana, A. (2018). A proposed game for promoting physical activities among people with low back pain using virtual reality. In Proceedings of the 11th PErvasive technologies related to assistive environments conference (PETRA '18). New York: ACM.

Bekele, M. K., Pierdicca, R., Frontoni, E., Malinverni, E. S., \& Gain, J. (2018). A survey of augmented, virtual, and mixed reality for cultural heritage. Journal on Computing and Cultural Heritage (JOCCH), $11(2), 7$.

Bernardes, M., Barros, F., Simoes, M., \& Castelo-Brancon, M. (2015). A serious game with virtual reality for travel training with autism Spectrum disorder. In International conference on virtual rehabilitation (ICVR), (pp. 127-128). Valencia: IEEE. https:// doi.org/10.1109//CVR.2015.7358609.

Boboc, A. L., Orzan, G., Stoica, l., \& Niculescu-Ciocan, C. (2018). Gamification and game-based learning- A solution for Romanian education system. The International Scientific Conference eLearning and Software for Education., 1, 242-248.

Bouali, N., Nygren, E., Oyelere, S. S., Suhonen, J., \& Cavalli-Sforza, V. (2019). A VR game to introduce OOP concepts. In 19th Koli calling international conference on computing education research (Koli calling '19). New York: ACM.

Bradshaw, T. (2016). Virtual reality: four ways it could change your world. https://www.ft.com/content/0f7d7ecc-db47-11e5a72f-1e $7744 c 66818 . \mathrm{html}$

Bryan, S. J., Campbell, A., \& Mangina, E. (2018). An AR/VR Educational Game. In IEEE games, entertainment, media conference (GEM), (pp. 1-9). Galway. https://doi.org/10.1109/GEM.2018.8516456.

Byl, B., Süncksen, B. M., \& Teistler, M. (2018). A serious virtual reality game to train spatial cognition for medical ultrasound imaging. In IEEE 6th international conference on serious games and applications for health (SeGAH), (pp. 1-4). https://doi. org/10.1109/SeGAH.2018.8401365.

Calvi, L., Santos, C. P., Relouw, J., Endrovski, B., Rothwell, C., Sarà, A., ... Pantaleo, U. (2017). A VR game to teach underwater sustainability while diving. In Sustainable internet and ICT for sustainability (Sustain/T' 2017), (pp. 1-4). https://doi.org/10. 23919/Sustain|T.2017.8379812.

Carvalheiro, C., Nóbrega, R., da Silva, H., \& Rodrigues, R. (2016). User redirection and direct haptics in virtual environments. In Proceedings of the 24th ACM international conference on multimedia, (vol. 5, pp. 1146-1155). 
Chin, C. S., Kamsani, N. B., Zhong, X., Cui, R., \& Yang, C. (2018). Unity3D serious game engine for high fidelity virtual reality training of remotely-Operated Vehicle Pilot. In Proc. 10th international conference on Modelling, identification and control (ICMIC), Guiyang, (pp. 1-6). https://doi.org/10.1109/ICMIC.2018.8529900.

Chittaro, L., \& Buttussi, F. (2015). Assessing knowledge retention of an immersive serious game vs. a traditional education method in aviation safety. In IEEE Transactions on Visualization and Computer Graphics. 21(4), 529-538. doi: https://doi. org/10.1109/TVCG.2015.2391853.

Chiu, F. (2017). Virtual reality for learning languages based on mobile devices. In 16th international conference on information technology based higher education and training (ITHET), (pp. 1-3). https://doi.org/10.1109/ITHET.2017.8067813.

Christou, C. (2010). Virtual Reality in Education. In Affective, interactive and cognitive methods for e-learning design: creating an optimal education experience, (pp. 228-243).

Cohen, C. A., \& Hegarty, M. (2014). Visualizing cross sections: Training spatial thinking using interactive animations and virtual objects. Learning and Individual Differences., 33, 63-71.

Diez, H. V., Andoni, S. G., Aitor, M., \& Oyarzun, D. (2016). Virtual training of fire wardens through immersive 3D environments. In Proceedings of the 21st international conference on Web3D technology (Web3D '16), (pp. 43-50). New York: ACM. https:// doi.org/10.1145/2945292.2945296.

Dinis, F. M., Guimarães, A. S., Carvalho, B. R., \& Martins, J. P. P. (2017). Development of virtual reality game-based interfaces for civil engineering education. In IEEE global engineering education conference (EDUCON), (pp. 1195-1202). https://doi.org/10. 1109/EDUCON.2017.7943000

Duffy, T. M., \& Jonassen, D. H. (1992). Constructivism and the designing of learning Environments: Technology of instruction: A conversation. Hillsdale N.J.: Lawrence Erlbaum. Computer and System Sciences, 105, 87-108. https://doi.org/10.1007/9783-642-78069-1.

Finkelstein, S., Nickel, A., Lipps, Z., Barnes, T., Wartell, Z., \& Suma, E. A. (2011). Astrojumper: motivating exercise with an immersive virtual reality Exergame. Presence Teleoperators and Virtual Environments., 20(1), 78-92.

Greenwald, S. W., Kulik, A., Kunert, A., Beck, S., Fröhlich, B., \& Cobb, S. (2017). Technology and Applications for Collaborative Learning in Virtual Reality. In Smith. Making a Difference: Prioritizing Equity and Access in CSCL. In 12th international conference on computer supported collaborative learning (CSCL), (vol. 2).

Gyutae, H., Hojun, L., Sangho, L., Jaekwang, C., \& Shiho, K. (2016). A VR serious game for fire evacuation drill with synchronized tele-collaboration among users. In 22nd ACM conference on virtual reality software and technology (VRST '16), (pp. 301-302). New York: ACM. https://doi.org/10.1145/2993369.2996306.

Hafsia, M., Monacelli, E., \& Martin, H. (2018). Virtual reality simulator for construction workers. In Proc. virtual reality international conference - Laval virtual (VRIC '18). https://doi.org/10.1145/3234253.3234298.

Hentsch, C. (2018, February, 9). Virtual Reality in Education: How VR can be Beneficial to the Classroom. https://edtechtimes. com/2018/02/09.

Heuven, R., Kinast, B., Thomas, A., Tabak, M., Cabrita, M., Schüler, T., \& Hörst, D. (2017). Dinner is ready!: Virtual Reality Assisted Training for Chronic Pain Rehabilitation. In ACM SIGCHI Annual Symposium on Computer-Human Interaction in Play (CHI PLAY), (vol. 17, pp. 283-289). CHI PLAY'.

Hwang, G. J., Wu, P. H., Chen, C. C., \& Tu, N. T. (2016). Effects of an augmented reality-based educational game on students' learning achievements and attitudes in real-world observations. Interactive Learning Environments., 24(8), 1895-1906.

Kaliisa, R., Edward, P., \& Julia, M. (2019). Mobile learning in higher education: A comparative analysis of developed and developing country contexts. British Journal of Educational Technology., 50(2), 546-561.

Kitchenham, B., \& Charters, S. (2007). Guidelines for performing systematic literature reviews in software engineering. Engineering., 45(4), 1051.

Knote, A., Edenhofer, S., \& Mammen, S. V. (2016). Neozoa: An immersive, interactive sandbox for the study of competing. In IEEE virtual reality workshop on K-12 Embodied Learning through Virtual \& Augmented Reality (KELVAR), (pp. 5-10). https:// doi.org/10.1109/KELVAR.2016.7563675.

Laine, T. H. (2018). Mobile educational augmented reality games: A systematic literature review and two case studies. Computers., 7(19), 11-15.

Lee, E. A. L., \& Wong, K. W. (2008). A review of using virtual reality for learning. Transactions on Edutainment, 1, $231-241$.

Lee, E. A. L., \& Wong, K. W. (2014). Learning with desktop virtual reality: Low spatial ability learners are more positively affected. Computers \& Education., 79, 49-58

Lee, E. A. L., Wong, K. W., \& Fung, C. C. (2010). How does desktop virtual reality enhance learning outcomes? A structural equation modeling approach. Computers \& Education, 55(4), 1424-1442 https//psycnet.apa.org >record.

Lele, A. (2013). Virtual reality and its military utility. Journal of Ambient Intelligent Human Computer., 4, 17-26.

Likitweerawong, K., \& Palee, P. (2018). The virtual reality serious game for learning driving skills before taking practical test. In International Conference on Digital Arts, Media and technology (ICDAMT), (pp. 158-161). https://doi.org/10.1109/ICDAMT. 2018.8376515

Linden, A., \& Fenn, J. (2003). Understanding Gartner's hype cycles. In Strategic Analysis Report Gartner, Inc., (pp. 20-1971).

Liu, W., Cheok, A. D., Mei-Ling, C. L., \& Theng, Y. L. (2007). Mixed reality classroom - learning from entertainment. ACM., 1(1), $65-72$.

Lovreglio, R., Gonzalez, V., Feng, Z., \& Sacks, R. (2018). Prototyping virtual reality serious games for building earthquake preparedness: The Auckland City Hospital case study. Advanced Engineering Informatics, 38, 670-682.

Mandal, S. (2013). Brief introduction of virtual reality \& its challenges. International Journal of Scientific \& Engineering Research., 4(4), 304.

Mihajlovic, Z., Popovic, S., \& Brkic, K. (2018). A system for head - Neck rehabilitation exercises based on serious gaming virtual reality. Multimed Tools and Applications., 77(15), 19113-19137.

Moher, D., Liberati, A., Tetzlaff, J., \& Altman, D. G. (2009). The PRISMA Group (2009) preferred reporting items for systematic reviews and meta-analyses. PLoS Med., 6(7):e1000097. https://doi.org/10.1371/journal.pmed.1000097.

Moldoveanu, A. D. (2017). Virtual environments for training visually impaired for a sensory substitution device. In Zooming Innovation in Consumer Electronics International Conference (ZINC), (pp. 26-29). https://doi.org/10.1109/ZINC.2017.7968654.

Nicas, J. (2018). What does virtual reality do to your body and mind? Wall Str J. http://www.wsj.com/articles/what-doesvirtual-reality-do-to-your-body-and-mind-1451858778. 
Oyelere, S. S., Suhonen, J., \& Laine, T. H. (2017). Integrating Parson's programming puzzles into a game-based mobile learning application. In Proc. Koli calling international conference on computing education research, (pp. 158-162).

Oyelere, S. S., Suhonen, J., Wajiga, G. M., \& Sutinen, E. (2018). Design, development, and evaluation of a mobile learning application for computing education. Education and Information Technologies, Springer., 23(1), 467-495.

Pavlidis, G. P., \& Markantonatou, S. (2018). Playful education and innovative gamified learning approaches. In Handbook of Research on Educational Design and Cloud Computing in Modern Classroom Settings, (pp. 321-341).

Pirker, J., Lesjak, I., \& Guetl, C. (2017). Maroon VR: A Room-Scale Physics Laboratory Experience. In IEEE 17th International Conference on Advanced Learning Technologies (ICALT), (pp. 482-484). https://doi.org/10.1109/ICALT.2017.92.

Puttawong, N., Visoottiviseth, V., \& Haga, J. (2017). VRFiWall virtual reality edutainment for firewall security concepts. In 2nd International Conference on Information Technology (INCIT), (pp. 1-6). https://doi.org/10.1109/INCIT.2017.8257864.

Roberto, A., Angela, C., Armando, F., Delfina, M., Donato, P., \& Mirta, R. (2017). A framework to design, develop, and evaluate immersive and collaborative serious games in cultural heritage. Journal on Computing and Cultural Heritage, 11(1). https:// doi.org/10.1145/3064644.

Roettl, J., \& Terlutter, R. (2018). The same video game in 2D, 3D or virtual reality-how does technology impact game evaluation and brand placements. PLoS One, 13(7), e0200724.

Sampaio, A. Z., Ferreira, M. M., Rosário, D. P., \& Martins, O. P. (2010). 3D and VR models in civil engineering education: Construction, rehabilitation and maintenance. Automation in Construction., 19(7), 819-828.

Sárkány, A. (2016). Maintain and improve mental health by smart virtual reality serious games. In Pervasive computing paradigms for mental health, (vol. 604). Cham: MindCare. Communications in Computer and Information Science, Springer.

Shahab, M. (2017). Social virtual reality robot (V2R): A novel concept for education and rehabilitation of children with autism. In 5th RSI International Conference on Robotics and Mechatronics (ICROM), (pp. 82-87). https://doi.org/10.1109/ICRoM.2017.8466148.

Sharkawi, K. H., Ujang, M. U., \& Abdul-Rahman, A. (2008). 3D navigation system for virtual reality based on 3D game engine. In The international archives of the photogrammetry, remote sensing and spatial information sciences, 37(PART B4).

Shin, D. H. (2017). The role of affordance in the experience of virtual reality learning. Telematics \& Informatics., 34(8), 18261836.

Snowdon, C. M., \& Oikonomou, A. (2018). Analysing the educational benefits of 3D virtual learning environments. In European conference on e-learning (513-XVIII). Kidmore End: Academic Conferences International Limited.

Süncksen, M., Bendig, H., Teistler, M., Wagner, M., Bott, O. J., \& Dresing, K. (2018). Gamification and virtual reality for teaching mobile x-ray imaging. In IEEE 6th international conference on Serious Games and Applications for Health (SeGAH), (vol. 7). https://doi.org/10.1109/SeGAH.2018.8401364.

Szczurowski, K., \& Smith, M. (2018). "Woodlands" - a virtual reality serious game supporting learning of practical road safety skills. In IEEE Games, Entertainment, Media conference (GEM), (pp. 1-9). https://doi.org/10.1109/GEM.2018.8516493.

Tabak, M., Miriam, C., Thomas, S., David, H., René, H., \& Benjamin, K. (2017). "Dinner is ready!": Virtual Reality Assisted Training for Chronic Pain Rehabilitation. In In extended abstracts publication of the annual symposium on computer-human interaction in play (CHI PLAY'17 extended abstracts), (pp. 283-289). ACM.

Triberti, S., Villani, D., \& Riva, G. (2016). Unconscious goal pursuit primes attitudes towards technology usage: A virtual reality experiment. Computers in Human Behavior., 64, 163-172.

Trombetta, M., Henrique, P. P. B., Brum, M. R., Colussi, E. L., Marchi, A. C. B., \& Rieder, R. (2017). Motion rehab AVE 3D: A VRbased exergame for post-stroke rehabilitation. Computer Methods and Programs in Biomedicine., 151, 15-20.

Tsoy, D., Sneath, P., Rempel, J., Huang, S., Bodnariuc, N., \& Mercuri, M. (2019). Creating GridlockED: A serious game for teaching about multipatient environments. Academic Medicine., 94(1), 66-70.

Tussyadiah, L. P., Wang, D., Jung, T. H., \& Dieck, M. C. (2018). Virtual reality, presence, and attitude change: Empirical evidence from tourism. Tourism Management., 66, 140-154.

Vesisenaho, M., Juntunen, M., Häkkinen, P., Pöysä-Tarhonen, J., Fagerlund, J., \& Miakush, I. (2019). Virtual reality in education: Focus on the role of emotions and physiological reactivity. Journal of Virtual Worlds Research., 12(1). https://doi.org/10. 4101/jvwr.v12i1.7329..

Virvou, M., \& Katsionis, G. (2008). On the usability and likeability of virtual reality games for education: The case of VR-ENGA GE. Computers \& Education, 50(1):154-178.

Visoottiviseth, V., Phungphat, A., Puttawong, N., Chantaraumporn, P., \& Haga, J. (2018). Lord of Secure: the Virtual Reality Game for Educating Network Security. In Seventh ICT International Student Project Conference (ICT-ISPC), (pp. 1-6). https:// doi.org/10.1109/ICT-ISPC.2018.8523947.

Voinea, G. D., Girbacia, F., Postelnicu, C. C., \& Marto, A. (2018). Exploring Cultural Heritage Using Augmented Reality Through Google's Project Tango and ARCore. In International conference on VR Technologies in Cultural Heritage, (pp. 93-106).

Vourvopoulos, A., Faria, A. L., Ponnam, K., \& Badia, S. B. (2014). RehabCity: design and validation of a cognitive assessment and rehabilitation tool through gamified simulations of activities of daily living. In Proc. 11th conference on advances in computer entertainment technology (ACE '14), Funchal, Portugal. https://doi.org/10.1145/2663806.2663852.

Xenos, M., Maratou, V., Ntokas, I., Mettouris, C., \& Papadopoulos, G. A. (2017). Game-based learning using a 3D virtual world in computer engineering education. In IEEE global Engineering Education Conference (EDUCON).

Zielke, M. A. (2017). Developing Virtual Patients with VR/AR for a natural user interface in medical teaching. In IEEE 5th international conference on Serious Games and Applications for Health (SeGAH), (pp. 1-8). https://doi.org/10.1109/SeGAH. 2017.7939285.

Zikky, M., Fathoni, K., \& Firdaus, M. (2018). Interactive distance media learning collaborative based on virtual reality with solar system subject. In 19th IEEE/ACIS international conference on software engineering, Artificial Intelligence, Networking and Parallel/Distributed Computing (SNPD), (pp. 4-9). https://doi.org/10.1109/SNPD.2018.8441031.

Zyda, M. (2005). From visual simulation to virtual reality to games. IEEE Computer Society. 37(9), 25-32. https://doi.org/10.1109/ MC.2005.297.

Publisher's Note

Springer Nature remains neutral with regard to jurisdictional claims in published maps and institutional affiliations. 